The Bible of Al ${ }^{\mathrm{TM}}$ OpenScience • Authors' publications

\title{
Influences on the Spanish language of English \\ translations based on Artificial Intelligence
}

Celia Medina Lloret, The Bible of Al ${ }^{\mathrm{TM}}$

Published on: Dec 13, 2021

License: $\underline{\text { Creative Commons Attribution-ShareAlike 4.0 International License (CC-BY-SA }}$ 4.0). 
Original version published in Spanish at ITVIA. Influencias en el idioma español de las traducciones del inglés basadas en Inteligencia Artificial

\section{Abstract}

Summarizing a text, differentiating and learning actions taken by subjets, is something remains out beyond the reach of any artificial intelligence? Because machines cannot reason but combine data and order them according to the preestabished algorithms. The study referred to an analysis about how machine translations based on Artificial Intelligence hold influence over Spanish language. It is studied for a possible mechanization of traditions (assigned roles to occupations), cultural and gender biases, even language discrimination (formal and informal). The work of machine translators become incompetent. Based on the results, we understand that the most accurate translator to interpret Spanish language is DeepL.

\section{Key words: artificial intelligence, Spanish language, machine translation, biases. \#AI \#ArtificialIntelligence \#Spanishlanguage \#Translation}

\section{1.- Introduction}

The task of translation carried with it the understanding, context, in which a sentence is pronounced, as well as cultural elements associated with, because these are global qualifiers in communication process. In the same way some specific elements in a sentence can vary and misrepresent its meaning. This is because these elements imply the use of reasoning (sometimes united at body expressions) and elements or historical and social behaviours to a proper interpretation.

Confronting, collating, valuing the translations made by humans vs 'intelligent' machines cannot be avoided because of the advent of more intelligent and powerful technological tools, associated to digital economies and optimal use of times. While the first ones (humans) are expensive resources and with a higher cost on time for their implementation, the second ones (machines) greatly reduce all of them. Prevailing in $5 \mathrm{G}$ era the immadiacy of translation with high availability and extension of capacity for use. Also, the globality of communication.

Although the evolution and new capacities of artificial intelligence are knocking down frontiers so far unimaginable. Google Translate [1] was one of the triggers and pioneers in the birth of this era for machine translations because of its incorporation in 
the browser in 2012 [2]. Previously, in 2006, Google Translate changed to statistical translation by only admitting English and Arabic language [ㅁ]. 1

In much the same way as words born and die with the use or misuse of societies, one might wonder if Artificial Intelligence (AI) can be an inductor that expedite this process in Spanish language. And, furthermore, this technology is contributing to improve and normalize Spanish language. Or, on contrary, it is a technology which impoverishes Spanish language and the corruption of guarantors and orthodox schemes backed by Spanish language academies in its human job. At the same time, the mechanization of translations can involve cultural biase, races and gender biase and even ideologies. Also a certain degree of handling in the transmitted ideas.

A language is the transmitter of human thought, generates ideas, and formulates reasonings. This, in the hands of Artificial Intelligence, we aim to analyse if the result is an additional value to spanish language and the universialization thereof. Or, on contrary, AI in translation should be regulated and supervised.

\section{2.-Main translators that use Artificial Intelligence}

Google Translate is a machine translation multilingual system developed by Google [4]. Such tasks may include text, voice, image and video translation in real time. This translation service uses Artificial Intelligence by implementing Neural Machine Translation (NMT) to the system [ㅁ].

Microsoft Translate is a machine translation service created by Microsoft [ㅁ]. Its major functions are text and speech translations []. This translator has two technologies; Statistical Machine Translation (SMT) and Neural Machine Translation (NMT) based on Artificial Intelligence [ㅁ]

DeepL is a machine translation system developped by Linguee team [ $\underline{9}$ ]. Its functions are the translation of written texts and documents. DeepL uses Artificial Intelligence by the use of Convolutional Neural Networks (CNNs) on the basis of the database of Linguee [10].

\section{3.-Artificial Intelligence technologies in translators}

The specific translators subject of study are based on Neural Machine Translation (NMT). Neural Machine Translation has been developed with the aim of overcoming the weaknesess that conventional translation systems have [11]. "NMT is an approach to machine translation that uses an artificial neural network to predict the likelihood of 
a sequence of words, typically modeling entire sentences in a single integrated model" [12].

\section{1-Neual Machine Translation models}

The monolingual NMT model is a simple system that trains an only one neural network in which data are sent via parallel transmission. This method of translation is labelled by a target language, that is, texts and words from other languages are translated to the target language [13] :

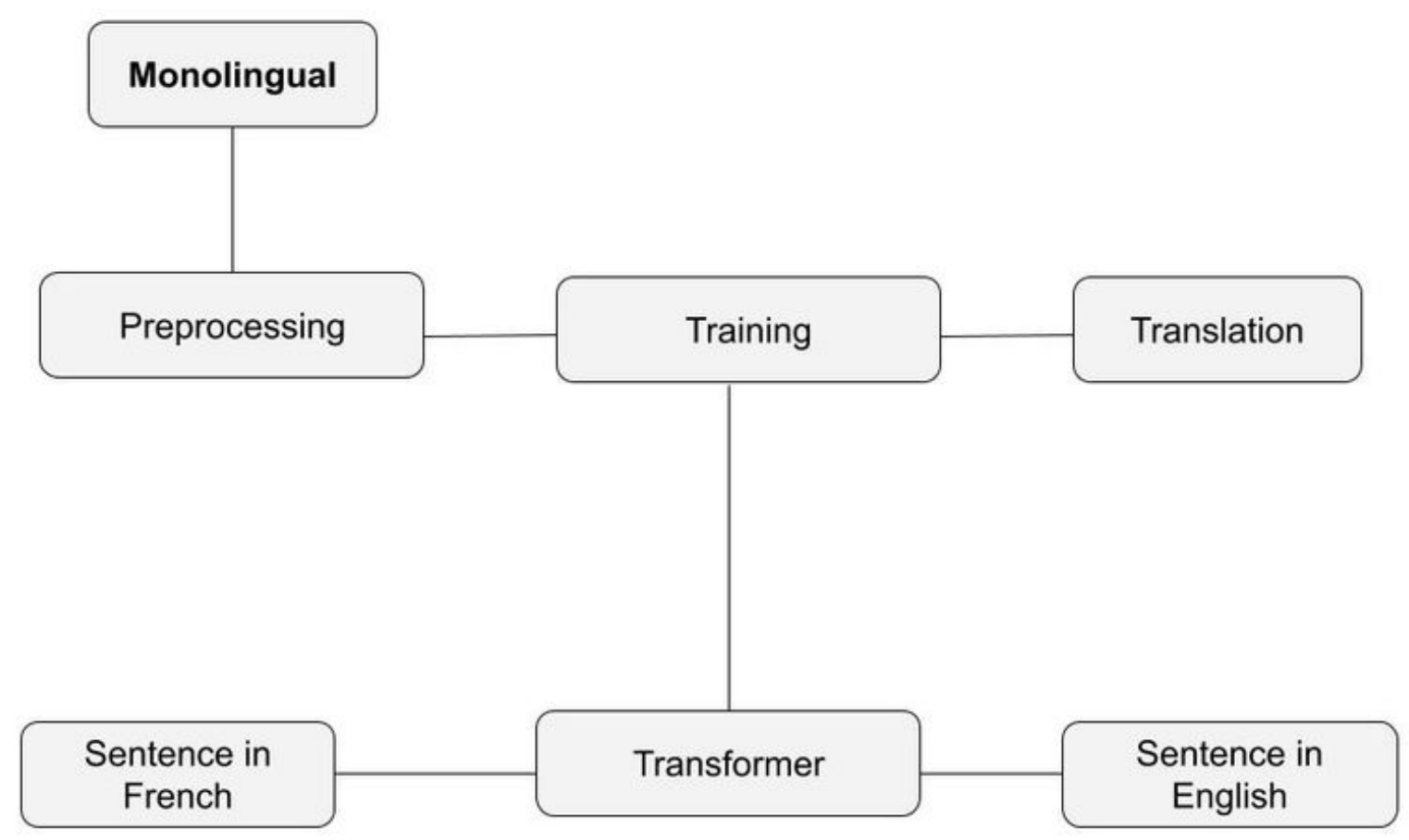

Image credit: NTM monolingual model. Deep Neural Transformer Model for Mono and Multi Lingual - Machine Translation. URL: http://ceur-ws.org/Vol2904/66.pdf

The multilingual NMT model is a trained system with available data in different languages, for instance, French (L1) and Arabic (L2). Both languages, L1 and L2 are combined together to collect data for training and translating. In this case translation evaluation will be conducting with the objective of getting accuracy. For that purpose, 
a token is added from source language to each target phrase by simulating the translation from several languages to one [1]ㄹ:

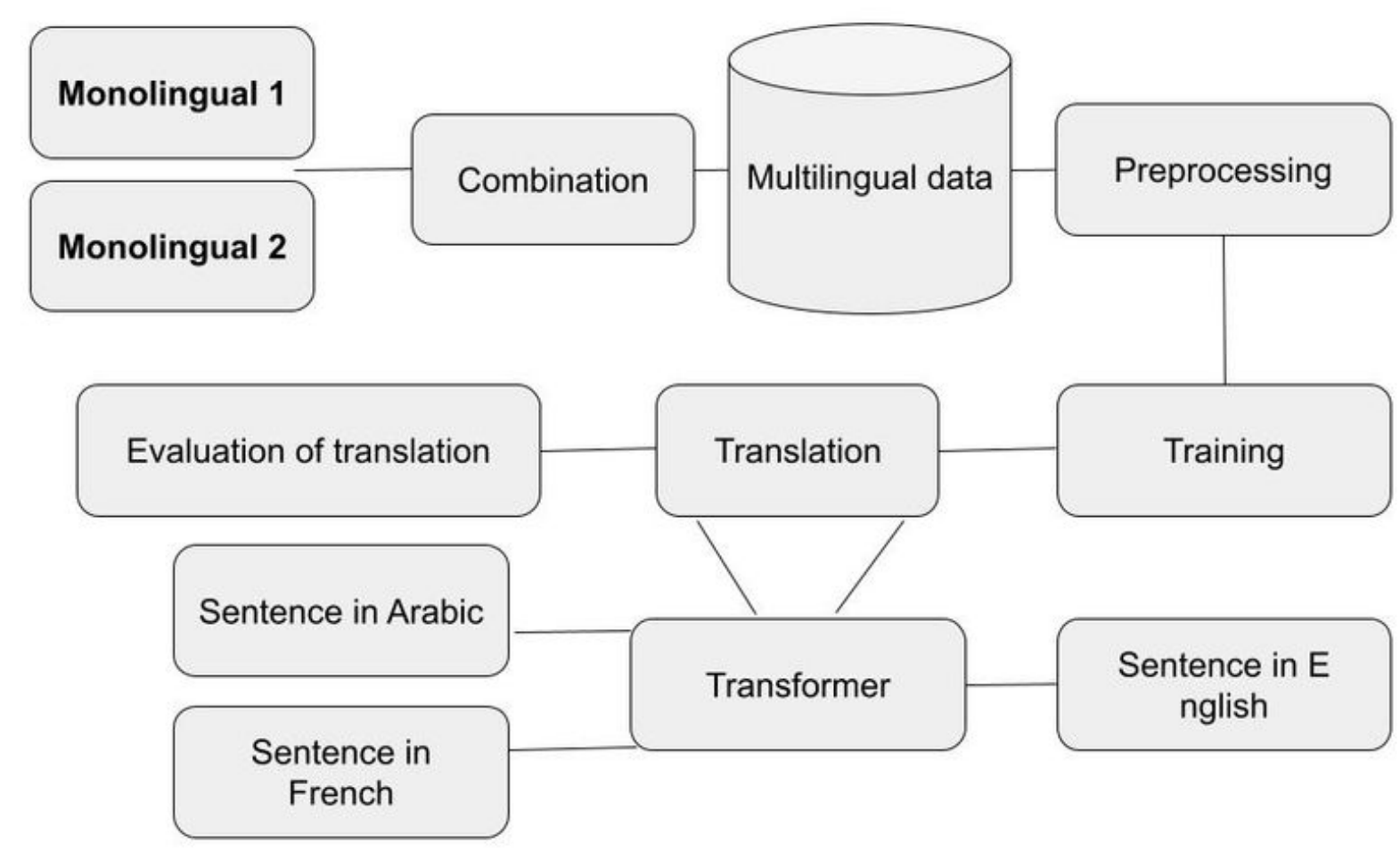

Image credit: NTM multilingual model. Deep Neural Transformer Model for Mono and Multi Lingual - Machine Translation. URL: http://ceur-ws.org/Vol2904/66.pdf

\section{4.- Programming languages that use the language translators}

Google Translate. The programming languages used are an architecture of services and API's layers created with: $\mathrm{C}++$, Java, Python, Javascript and Go, inspired in the syntax of C. As well as programming languages, Google Translate works the combination of data with a specific software for Statistical Machine Translation [14]. Some of those are: Apache Joshua Home, used for hierarchy and syntax in machine translation [15]. Giza ++ is used for training statistical model of translation [16]. Moses allows translating automatically models in any language by an efficient algorithm of search that find the most accuracy translation between several options [17]. Google 
Translate has Google Trans [18], a Python bookstore that implements in the API of Google Translate [19].

Microsoft Translator. The API of Microsoft Translator offers an improved online translation version by the implementation of Microsoft Translation API bookstore for Python, which is developed in Python [20].

DeepL called for the launching of a Python client bookstore for the API of DeepL with the objetive of maintaining DeepL's functions and provide the task of developers in order to create applications with DeepL [20].

Miguel Rebollo, who holds a doctorate of artificial intelligence by Technical University of Valencia, says that Python is the best programming language for machine translation because there are many learning bookstores which facilitate the task [21]. These statements along with Rafael Vargas, general director of deep learning R, LLC, who claims that Python bookstores are the most used in deep learning; Pandas, Scypy y Scikit-learn, Keros and Tensorflow. Similarly, R language with packages as rminer and tidyverse [22].

\section{5.-Artificial Intelligence algorithms in language translators}

In recent years, artificial intelligence has required an important impetus for machine translation because it has allowed a major understanding of texts by contextualizing details. To do this, the algorithms have been 'fed' with many texts from different languages in order to improve their eficiency and eliminate «undeserved languages», according to Marta R. Costa-Jussà [를.

Google Translate uses BERT (Bidirectional Encoder Representations from Transformers), a linguistic model developed by Google. It is a technique based on neural networks for the pretraining of natural language programming developed by Google [24]. What advantages Bert brings to AI in translation process? It offers a better performance of the model, it improves the capacity of processing large amounts of texts and languages, it shows options of easy route to use models previously trained, it increases the capacity to set data to the context of a language and it is capable to apply to data, that are not previously trained, giving as an answer a very effective model [25].

Microsoft Translator applies artificial intelligence to translations by using neural networks [26] . In last year, Microsoft Translator has benefited from updatings turned by the $\mathrm{Z}$ code, as part of the code initiative XYZ of Microsoft. Through a combination of 
models based on artificial intelligence, an initiative has been developed. This initiative focuses on the creation of multilingual linguistic models. It suposses more benefits in translation, for example: improving the accuracy in translations of languages which have less than one thousands of training sentences by combining families and languages models [르].

\section{6.- Analysis and comparative of translated sentences, results, and influences in Spanish language that result from English translators}

Following the previous section, it should be added that machine translation also generate distortion and gender problems in languages. For this reason, in next paragraphs, we evidence what the main difficulties are found in machine translation.

\section{1.- Gender bias in machine translation}

The interest in understanding and mitigating gender bias is growing up in natural programming language. In fact, recent studies show that gender differentials affect to language technologies. In some cases, machine translators consider the feminine pronoun "she" as a pronoun from masculine gender. However, this translation is not relevant in languages without grammatical gender, as in the case of: Turkish, Finnish and Hungarian. The same conditions cannot be applied to French and Spanish language because they are considered as languages with grammatical gender. When we speak about grammatical gender, we refer to many parts of the discourse: names, verbs, determinants, adjectives have gender inflection [28].

In next paragraphs, we analyse what measures adopt the machine translators, which have been selected for the research, to prevent gender bias.

Google Translate. Progress on neural machine translations provide more naturality and fluency in translations. Moreover, the appearance stereotypes and cultural and social biases have provoked that machine translators develop new techniques to reduce gender discrimination in this sector. For it, Google creates a dataset that consists of grouping descriptions by geography, gender and work without skipping any region in the world. With this dataset contextual errors referred to gender have been reduced by $67 \%$ though this may contain mistakes. Let's see how Google translates this sentence from English to Spanish language: Marie Curie was born in Warsaw. The distinguished scientist received the Nobel Prize in Physics in 1903 (English) - Marie Curie nació en Varsovia. El distinguido científico recibió el Premio Nobel de Física en 1903 (Spanish). Now, let's see the difference in the translation by applying Google's dataset: Marie Curie nació en Varsovia. La distinguida científica recibió el Premio 
Nobel de Física en 1903. The main objetive is that models learn generating pronouns from a specific gender and contextualize them [29].

Bing Microsoft Translator. This machine translator does not offer possible options in the translation itself, however, it shows synonymous and usage examples. At times, the feminine form of a word can appear although in a systematic manner. If we write the word "beautiful" to translate to Spanish, the results are: bella and hermosa. By contrast, according to the previous example, it was noted that the translation of sentences to Spanish language are not totally correct because the gender of the words is not appropriate: Marie Curie nació en Varsovia. El distinguido científico recibió el Premio Nobel de Física en 1903.

DeepL. This machine translator, like Bing Microsoft Translate, offers possible gender options in process of translating a word. DeepL is a machine translator that sustains gender in a context. Based on our example, DeepL appropiately translates to Spanish: Marie Curie nació en Varsovia. La distinguida científica recibió el Premio Nobel de Física en 1903.

Next table shows the frequency of masculine and feminine gender usage in adjectives in Google Translate (GT), Bing Microsoft Translator (BMT) and DeepL (DL) [무] .

\begin{tabular}{|l|l|l|l|}
\hline Adjectives & GT & BMT & DL \\
\hline Masculine & $37,3 \%$ & $1,5 \%$ & $22,8 \%$ \\
\hline Feminine & $39,2 \%$ & $58,8 \%$ & $45,6 \%$ \\
\hline
\end{tabular}

Regarding gender, occupations are subjected to discriminations in machine translations.

To check this theory, we take as a sign ten occupations: gardener, nurse, doctor, teacher, trainer, babysitter, lawyer, engineer, computer scientist and seamstress. Then, we look for the translation into Spanish in Google Translate, Bing Microsoft Translator and DeepL to get these results: jardinero, enfermera, médico, profesor, entrenador, niñera, abogado, ingeniero, informático and costurera. It is clear that gender inequality in working environment contributes to the development of sexist language. A clear example of this is the translation of nurse, babysitter and seamstress. Machine translators assign these occupations by default to feminine gender, presuming that care jobs are directly vinculated to women. Meanwhile occupations such as lawyer, 
engineer and doctor, which are considered as intelligent jobs, they are linked to masculine gender. This is an indication that algorithms and artificial intelligence systems learn from examples which have been previously created by society, recreating human errors [피].

\section{6.-2 Bias of the informal linguistic register in machine translation}

Artificial intelligence enforcement in machine translation has improved the contextualization of information that the translator has. To do it, the databases, which have been used in trade agreements, European Union laws and United Nations protocols have been reviewed. By this way, algorithms are provided with several references which are translated to many languages. At the same time, this way of training create a bias to formal register language (vernacular expressions, street jargon, idioms, sayings and folk sayings), because all the mentioned documents are written in formal language [르].

To verify that machine translators 'carry away' the formal language from vocabulary, we test ten expressions from English jargon and we analyse the translation into Spanish language made by machine translators:

- What's the tea? and the translation into Spanish is: ¿Cuál es el chisme?

\begin{tabular}{|l|l|l|l|}
\hline Translators & Google Translate & Microsoft Translator & DeepL Translate \\
\hline Translation (En - Sp) & ¿Qué es el té? & ¿Qué es el té? & ¿Qué es el té? \\
\hline
\end{tabular}

- Omg wig flew! and the translation into Spanish is: ¡Qué disparate!

\begin{tabular}{|l|l|l|l|}
\hline Translators & Google Translate & Microsoft Translator & DeepL Translate \\
\hline Translation(En - Sp) & $\begin{array}{l}\text { ¿Dios mío, la peluca } \\
\text { voló! }\end{array}$ & Omg peluca voló & Omg la peluca voló \\
\hline
\end{tabular}

- The law straw and the translation into Spanish is: la gota que colma el vaso

\begin{tabular}{|l|l|l|l|}
\hline Translators & Google Translate & Microsoft Translator & DeepL Translate \\
\hline Translation (En - Sp) & La última gota & $\begin{array}{l}\text { La gota que colma el } \\
\text { vaso }\end{array}$ & $\begin{array}{l}\text { La gota que colma el } \\
\text { vaso }\end{array}$ \\
\hline
\end{tabular}


- To go pear-shaped and the translation into Spanish is: ir por mal camino

\begin{tabular}{|l|l|l|l|}
\hline Translators & Google Translate & Microsoft Translator & DeepL Translate \\
\hline Translation (En - Sp) & Ir en forma de pera & $\begin{array}{l}\text { Para ir en forma de } \\
\text { pera }\end{array}$ & Para ir en picado \\
\hline
\end{tabular}

- Easy-peasy and the translation into Spanish is: pan comido

\begin{tabular}{|l|l|l|l|}
\hline Translators & Google Translate & Microsoft Translator & DeepL Translate \\
\hline Translation (En - Sp) & Pan comido & Peasy-fácil & Fácil \\
\hline
\end{tabular}

- A stitch in time saves nines and the translation into Spanish is: más vale prevenir que curar

\begin{tabular}{|l|l|l|l|}
\hline Translators & Google Translate & Microsoft Translate & DeepL Translate \\
\hline Translation (En - Sp) & $\begin{array}{l}\text { Una puntada a } \\
\text { tiempo ahorra nueve }\end{array}$ & $\begin{array}{l}\text { Mue lamentar } \\
\text { que } \text { lamenir }\end{array}$ & $\begin{array}{l}\text { Una puntada a } \\
\text { tiempo salva nueve }\end{array}$ \\
\hline
\end{tabular}

- Absence makes the heart grow fonder and the translation into Spanish is: nadie sabe lo que tiene hasta que lo pierde

\begin{tabular}{|l|l|l|l|}
\hline Translators & Google Translate & Microsoft Translate & DeepL Translate \\
\hline Translation (En - Sp) & $\begin{array}{l}\text { La ausencia hace } \\
\text { crecer el cariño }\end{array}$ & $\begin{array}{l}\text { La ausencia hace que } \\
\text { el corazón se haga } \\
\text { más cariñoso }\end{array}$ & $\begin{array}{l}\text { La ausencia hace que } \\
\text { el corazón se haga } \\
\text { más cariñoso }\end{array}$ \\
\hline
\end{tabular}

- Feeling a bit under the weather and the translation into Spanish is: estar pachucho

\begin{tabular}{|l|l|l|l|}
\hline Translators & Google Translate & Microsoft Translate & DeepL Translate \\
\hline Translation (En - Sp) & $\begin{array}{l}\text { Sintiéndome un poco } \\
\text { mal }\end{array}$ & Sentirse mal & $\begin{array}{l}\text { Se siente un poco } \\
\text { mal }\end{array}$ \\
\hline
\end{tabular}

- Beggars can't be choosers and the translation into Spanish is: cuando hay hambre no hay pan duro 


\begin{tabular}{|l|l|l|l|}
\hline Translators & Google Translate & Microsoft Translate & DeepL Translate \\
\hline Translation (En - Sp) & $\begin{array}{l}\text { Los mendigos no } \\
\text { pueden ser } \\
\text { selectores }\end{array}$ & $\begin{array}{l}\text { Los mendigos no } \\
\text { pueden ser elegidos }\end{array}$ & $\begin{array}{l}\text { Los mendigos no } \\
\text { pueden elegir }\end{array}$ \\
\hline
\end{tabular}

- You scratch my back, and I'll scratch yours and the translation into Spanish is: hoy por ti, mañana por mi

\begin{tabular}{|l|l|l|l|}
\hline Translators & Google Translate & Microsoft Translate & DeepL Translate \\
\hline Translation (En - Sp) & $\begin{array}{l}\text { Tú me rascas la } \\
\text { espalda y yo rasco la } \\
\text { tuya }\end{array}$ & $\begin{array}{l}\text { Tú me rascas la } \\
\text { espalda y yo te rasco } \\
\text { la tuya }\end{array}$ & $\begin{array}{l}\text { Tú me rascas la } \\
\text { espalda y yo te rasco } \\
\text { la tuya }\end{array}$ \\
\hline
\end{tabular}

Following the analysis, we focus on the results that only $\mathbf{4}$ of $\mathbf{3 0}$ machine translations correctly interpret the meaning of the expression in Spanish language. 5 translations are similar intepreted to the original meaning and the rest of them, that's $\mathbf{2 1}$, are literal translations of the written setence in the origin language; English. Therefore, we deduce that the formal register from Spanish language is not completely included in machine translation. But, is informal register less important and needed than formal register? Is it a negative point for Spanish language?

In 1991 César Hernández Alonso stated in the European Asociation of Spanish Professors Review that a slang expression is an spontaneous way of communicating and it is the most used. By using sayings and nested sentences we give opinions, express thoughts, ideas, give advices as well as the way of being in life. For this reason, César Hernández Alonso enhances this linguistic register. It is an expression of extraordinary diversity [푹.

“El hombre es el lenguaje. A través de esa facultad casi divina del ser humano, en una de sus realizaciones o lenguas, obtenemos una concepción o sentido de la vida y de las cosas, en una lengua pensamos, nos expresamos y aún sentimos.“ (Hernández Alonso, 1991, 38-39)

[The man is the language. With this faculty almost divine of human being, in one of its realizations or languages, we get a conception or sense of the life and things. We use a language to think, to express ourselves and feel. (Hernández Alonso, 1991, 38-39) ] 
There are words from English origin that we daily use independently of our language, however, the translation to another language as Spanish, Germany, Portuguese, French or Swedish cannot be literal because these words don't exist in target languages. That is a mistake that machine translators do, as we can see in the next examples:

\section{- Example A. Don't give any spoilers.}

\begin{tabular}{|l|l|l|l|}
\hline Translators & Google Translate & Microsoft Translator & DeepL Translator \\
\hline Translation (En - Sp) & No des spoilers & No des spoilers & $\begin{array}{l}\text { No dar ningún } \\
\text { spoiler }\end{array}$ \\
\hline Translation (En - Deu) & Nicht spoilern & $\begin{array}{l}\text { Geben Sie keine } \\
\text { Spoiler }\end{array}$ & $\begin{array}{l}\text { Keine Spoiler } \\
\text { verraten }\end{array}$ \\
\hline Translation (En - Pt) & Não dê spoilers & $\begin{array}{l}\text { Não dar quaisquer } \\
\text { spoilers }\end{array}$ & $\begin{array}{l}\text { Não dar nenhum } \\
\text { spoilers }\end{array}$ \\
\hline Translation (En - Fr) & $\begin{array}{l}\text { Ne donnez pas de } \\
\text { spoils }\end{array}$ & $\begin{array}{l}\text { Ne donnez pas de } \\
\text { spoilers }\end{array}$ & $\begin{array}{l}\text { Ne donne pas de } \\
\text { spoilers }\end{array}$ \\
\hline Translation (En - Swe) & Ge inga spoilers & Ge inga spoilers & $\begin{array}{l}\text { Inte ge några } \\
\text { spoilers }\end{array}$ \\
\hline
\end{tabular}

The word spoiler is a patent anglicism. It is formed by the suffix -er, indicating agent, with the verb spoil that means diminish or destroy something [프]. According to the results of the previous table, the word spoiler is translated in all languages in the same way that it was written in the original language. So it could be an evidence that spoiler is not a word recognised by the target language. Considering what would happen with Spanish language, the focus of our research. The word spoiler in Spanish does not exist because it is not recognised by the Royal Academy of Spanish Language, that is, one of the most important cultural entites dedicated to regularise the linguistic in the Spanish-speaking countries [ㅌ5]. Therefore, this word should not be translated as spoiler because it is not correct. The appropiate translation is no me desveles ningún detalle.

\section{- Example B. Hashtag.}

\begin{tabular}{|l|l|l|l}
\hline Translators & Google Translate & Microsoft Translator & DeepL Translate
\end{tabular}




\begin{tabular}{|l|l|l|l|}
\hline Translation (En - Sp) & Hashtag & Hashtag & Hashtag \\
\hline Translation (En - Deu) & Hashtag & Hashtag & Hashtag \\
\hline Translation (En - Pt) & Hashtag & Hashtag & Hashtag \\
\hline Translation (En - Fr) & Hashtag & Hashtag & Hashtag \\
\hline Translation (En - Swe) & Hashtag & Hashtag & Hashtag \\
\hline
\end{tabular}

The word hashtag is anglosaxon. It is composed of two english terms hash and tags, referred to something that is classified or categorised [ㅎ6]. In the previous table, the translations of the word hashtag is hastag. As with the word spoiler, this word is not recognised by target languages. Therefore, the translation of hashtag is incorrect even thought the most of speakers introduce this word in their common vocabulary. In Spanish language, the most accurate translation of hashtag is etiqueta.

\begin{tabular}{|l|l|l|l|}
\hline Translators & Google Translate & Microsoft Translator & DeepL Translate \\
\hline Translation (En - Sp) & Smartphone & Teléfono inteligente & Smartphone \\
\hline Translation (En - Deu) & Smartphone & Smartphone & Smartphone \\
\hline Translation (En - Pt) & Smartphone & Smartphone & Smartphone \\
\hline Translation (En - Fr) & Téléphone intelligent & Smartphone & Smartphone \\
\hline Translation (En - Swe) & Smartphone & Smartphone & Smartphone \\
\hline
\end{tabular}

The word smartphone is a linguistic loan from English language [국. The Royal Academy for Spanish Language does not register this word in the vocabulary, thus, using smartphone in our day a day Spanish vocabulary is not appropriate. We should say teléfono inteligente rather than smartphone. The same conditions for the rest of languages reflected on the table.

\section{3.- Ambiguity in machine translation for English-Spanish languages}

In general terms, machine translation is an important advance in translation tasks. However, ambiguity is recognised as a linguistic difficulty in machine translation [으. The Royal Academy for Spanish Language defines ambiguous as a feature of language that could be understood in different ways or admit many interpretations. Moreover 
ambiguity could provokes confusion and uncertainty to translate sentences [39]. The problem of ambiguity in machine translation is the incapacity to determine if the information could be understood in more than one context [40]. To ensure that ambiguity is a problem that should be resolved by computational linguistic, we analyse the following examples [41].

- Case one. The dog bit the man at the door. There are two possible translations to Spanish language: el perro mordió al hombre en la puerta y el perro mordió al hombre que estaba en la puerta.

\begin{tabular}{|l|l|l|l|}
\hline Translators & Google Translate & Microsoft Translator & DeepL Translate \\
\hline Translation (En - Sp) & $\begin{array}{l}\text { El perro mordió al } \\
\text { hombre en la puerta }\end{array}$ & $\begin{array}{l}\text { El perro mordió al } \\
\text { hombre en la puerta }\end{array}$ & $\begin{array}{l}\text { El perro mordió al } \\
\text { hombre en la puerta }\end{array}$ \\
\hline
\end{tabular}

- Case two. The inspector arrested the holigan with a drone. There are two possible translations to Spanish language: la inspectora arrestó al gamberro, quien tenía un dron y la inspectora arrestó al gamberro utilizando un dron.

\begin{tabular}{|l|l|l|l|}
\hline Translators & Google Translate & Microsoft Translator & DeepL Translate \\
\hline Translation (En - Sp) & $\begin{array}{l}\text { El inspector arrestó } \\
\text { al gamberro con un } \\
\text { dron }\end{array}$ & $\begin{array}{l}\text { al gamspector arrestó } \\
\text { dron }\end{array}$ & $\begin{array}{l}\text { El inspector detuvo } \\
\text { al gamberro con un } \\
\text { dron }\end{array}$ \\
\hline
\end{tabular}

- Case three. The lady hit the man with the umbrella. There are two possible translations to Spanish language: la mujer golpeó al hombre que llevaba un paraguas y la mujer golpeó al hombre utilizando un paraguas.

\begin{tabular}{|l|l|l|l|}
\hline Translators & Google Translate & Microsoft Translator & DeepL Translate \\
\hline Translation (En - Sp) & $\begin{array}{l}\text { La dama golpeó al } \\
\text { hombre con el } \\
\text { paraguas }\end{array}$ & $\begin{array}{l}\text { La señora golpeó al } \\
\text { hombre con el } \\
\text { paraguas }\end{array}$ & $\begin{array}{l}\text { La señora golpeó al } \\
\text { hombre con el }\end{array}$ \\
paraguas
\end{tabular}

These three cases represent examples of grammar ambiguity. It is linguistic phenomenon which is produced when one sentence has two syntacic structures and each one has a different meaning [42]. 
- Case four. My glasses have broken. There are two possible translations to Spanish language: se me han roto las gafas y se me han roto los vasos.

\begin{tabular}{|l|l|l|l|}
\hline Translators & Google Translate & Microsoft Translator & DeepL Translate \\
\hline Translation (En - Sp) & $\begin{array}{l}\text { Mis lentes se han } \\
\text { roto }\end{array}$ & Mis gafas se han roto & $\begin{array}{l}\text { Mis lentes se han } \\
\text { roto }\end{array}$ \\
\hline
\end{tabular}

- Case five. Refill the barrel. There are two possible translations to Spanish language: recargar el cañón y recargar el barril.

\begin{tabular}{|l|l|l|l|}
\hline Translators & Google Translate & Microsoft Translator & DeepL Translate \\
\hline Translation (En - Sp) & Rellenar el barril & Rellenar el barril & Rellenar el barril \\
\hline
\end{tabular}

If we introduce this sentence in a context, the meaning changes, for example, he refills the barrel with bullets. It is translated in Spanish such as: recarga el cañón con balas. Or he refills the barrel with wine, rellenó el barril con vino. We see what happens in machine translators.

\begin{tabular}{|l|l|l|l|}
\hline Translators & Google Translate & Microsoft Translator & DeepL Translate \\
\hline Translation (En - Sp) & $\begin{array}{l}\text { Él vuelve a llenar el } \\
\text { cañón de balas }\end{array}$ & $\begin{array}{l}\text { Rellena el cañón con } \\
\text { balas }\end{array}$ & $\begin{array}{l}\text { Rellena el cañón con } \\
\text { balas }\end{array}$ \\
\hline Translators & Google Translate & Microsoft Translator & DeepL Translate \\
\hline Translation (En - Sp) & $\begin{array}{l}\text { Llenó el barril con } \\
\text { vino }\end{array}$ & $\begin{array}{l}\text { Volvió a llenar el } \\
\text { barril con vino }\end{array}$ & $\begin{array}{l}\text { Llenó el barril con } \\
\text { vino }\end{array}$ \\
\hline
\end{tabular}

- Case six. There is a mouse under the table. There are two possible translations to Spanish language: hay un roedor debajo de la mesa and hay un ratón debajo de la mesa.

\begin{tabular}{|l|l|l|l|}
\hline Translators & Google Translate & Microsoft Translator & DeepL Translate \\
\hline Translation (En - Sp) & $\begin{array}{l}\text { Hay un ratón debajo } \\
\text { de la mesa }\end{array}$ & $\begin{array}{l}\text { Hay un ratón debajo } \\
\text { de la mesa }\end{array}$ & $\begin{array}{l}\text { Hay un ratón bajo la } \\
\text { mesa }\end{array}$ \\
\hline
\end{tabular}


If we add more information to this sentence its meaning changes. For example, there is a mouse under the table, kill it is translated into Spanish as hay un ratón debajo de la mesa, mátalo. Or there is a mouse under the table, use it to replace the damaged one is translated into Spanish as hay un ratón debajo de la mesa; cógelo y cámbialo por el que no funciona. We see what happens in machine translators.

\begin{tabular}{|c|c|c|c|}
\hline Translators & Google Translate & Microsoft Translator & DeepL Translate \\
\hline Translation (En - Sp) & $\begin{array}{l}\text { Hay un ratón debajo } \\
\text { de la mesa, mátalo }\end{array}$ & $\begin{array}{l}\text { Hay un ratón debajo } \\
\text { de la mesa, mátalo }\end{array}$ & $\begin{array}{l}\text { Hay un ratón debajo } \\
\text { de la mesa, mátalo }\end{array}$ \\
\hline Translators & Google Translate & Microsoft Translator & DeepL Translate \\
\hline Translation (En - Sp) & $\begin{array}{l}\text { Hay un ratón debajo } \\
\text { de la mesa; úselo } \\
\text { para reemplazar el } \\
\text { dañado uno }\end{array}$ & $\begin{array}{l}\text { Hay un ratón debajo } \\
\text { de la mesa; úselo } \\
\text { para reemplazar el } \\
\text { dañado uno }\end{array}$ & $\begin{array}{l}\text { Hay un ratón debajo } \\
\text { de la mesa; úselo } \\
\text { para reemplazar el } \\
\text { dañado }\end{array}$ \\
\hline
\end{tabular}

The three last examples represent cases of syntactic ambiguity, that is, a word admits two or more different meanings [42]. However, when a word is followed by other information, machine translators distinguish between, for example, glasses; vasos and glasses; gafas.

By analysing these cases, we conclude that ambiguity and informal register in a language represent the main problem facing machine translators. This is mainly due to the lack of knowledge of Spanish language. This, no doubt, is a negative point for machine translators because they don't offer accurate translations. So, this negativily affects to Spanish language.

\section{7.- Can you translate emotions?}

The systems that incorporate artificial intelligence don't require the identification of human feelings, as they are capable of doing a proposed task [녀] . However, Does it occur with machine translators? The algorithms which are involved in machine translation tasks have some difficulties by translating emotions [44], as for example literary figures in poetic style. To support this, we choose some verses from different poems in the English language and we analyse the translations of Google Translate, 
DeepL and Microsoft Translate. Finally, we test if AI is valid to get an accurate emotional translation.

The first five lyrics belong to the poem The Road Not Taken, which was written by the American poet Robert Frost [4ㄷ].

Table 25

\begin{tabular}{|l|l|l|l|}
\hline Original text (En) & Google Translate & Microsoft Translator & DeepL Translate \\
\hline $\begin{array}{l}\text { (v1) Two roads } \\
\text { diverged in a yellow } \\
\text { wood, }\end{array}$ & $\begin{array}{l}\text { Dos caminos } \\
\text { divergieron en un } \\
\text { bosque amarillo, }\end{array}$ & $\begin{array}{l}\text { Dos caminos } \\
\text { divergieron en un } \\
\text { bosque amarillo, }\end{array}$ & $\begin{array}{l}\text { Dos caminos se } \\
\text { bifurcan en un bosque } \\
\text { amarillo, }\end{array}$ \\
\hline $\begin{array}{l}\text { (v2) And sorry I could } \\
\text { not travel both }\end{array}$ & $\begin{array}{l}\text { Ylo siento, no pude } \\
\text { viajar tanto }\end{array}$ & $\begin{array}{l}\text { Y lo siento, no pude } \\
\text { viajar ambos }\end{array}$ & $\begin{array}{l}\text { Y siento no haber } \\
\text { podido viajar los dos }\end{array}$ \\
\hline $\begin{array}{l}\text { (v3) And be one } \\
\text { traveler, long I stood }\end{array}$ & $\begin{array}{l}\text { Y ser un viajero, } \\
\text { durante mucho tiempo } \\
\text { me quedé }\end{array}$ & $\begin{array}{l}\text { Y sé un viajero, mucho } \\
\text { tiempo estuve de pie }\end{array}$ & $\begin{array}{l}\text { Y ser un viajero, mucho } \\
\text { tiempo estuve }\end{array}$ \\
\hline $\begin{array}{l}\text { (v4) And looked down } \\
\text { one as far as I could }\end{array}$ & $\begin{array}{l}\text { Y miré hacia abajo, uno } \\
\text { tan lejos como pude }\end{array}$ & $\begin{array}{l}\text { Y miré hacia abajo uno } \\
\text { hasta donde pude }\end{array}$ & $\begin{array}{l}\text { Y miré hacia abajo, } \\
\text { hasta donde pude }\end{array}$ \\
\hline $\begin{array}{l}\text { (v5) To where it bent in } \\
\text { the undergrowth; }\end{array}$ & $\begin{array}{l}\text { A donde se inclinó en la } \\
\text { maleza; }\end{array}$ & $\begin{array}{l}\text { A donde se dobló en la } \\
\text { maleza; }\end{array}$ & $\begin{array}{l}\text { Hasta donde se dobló } \\
\text { en la maleza; }\end{array}$ \\
\hline
\end{tabular}

In the next table it appears the human translation of the poem The Road Not Taken. The translation into Spanish implies the loss of the metric in all lyrics with the exception of lyric number 2.

\section{Table 26}

\begin{tabular}{|c|c|}
\hline Original text (En) & Human translation $(\mathrm{Sp})$ \\
\hline (v1) Two roads diverged in a yellow wood, & Dos caminos se bifurcaron en un áureo bosque, \\
\hline (v2) And sorry I could not travel both & Y apenado no pude andar entrambos \\
\hline (v3) And be one traveler, long I stood & $\begin{array}{l}Y \text { siendo un solitario viajero, un buen rato de pie } \\
\text { estuve }\end{array}$ \\
\hline
\end{tabular}


(v4) And looked down one as far as I could Y en uno de ellos tendí la mirada tan lejos como pude

The second example makes reference to the lyrics 1 to 4 from the poem The Tyger, which was written by the British poet, William Blake [뜨].

Table 27

\begin{tabular}{|l|l|l|l|}
\hline Original text (En) & Google Translate & Microsoft Translator & DeepL Translate \\
\hline $\begin{array}{l}\text { (v1) Tyger, tyger, } \\
\text { burning bright }\end{array}$ & $\begin{array}{l}\text { Telas, telas, ardiendo } \\
\text { brillante }\end{array}$ & $\begin{array}{l}\text { Tyger, tyger, ardiendo } \\
\text { brillante }\end{array}$ & Tyger, tyger, ardiente \\
\hline $\begin{array}{l}\text { (v2) In the forests of } \\
\text { the night }\end{array}$ & $\begin{array}{l}\text { En los bosques de la } \\
\text { noche }\end{array}$ & $\begin{array}{l}\text { En los bosques de la } \\
\text { noche }\end{array}$ & $\begin{array}{l}\text { En los bosques de la } \\
\text { noche }\end{array}$ \\
\hline $\begin{array}{l}\text { (v3) What immortal } \\
\text { hand or eye }\end{array}$ & $\begin{array}{l}\text { Que mano u ojo } \\
\text { inmortal }\end{array}$ & $\begin{array}{l}\text { Qué mano u ojo } \\
\text { inmortal }\end{array}$ & $\begin{array}{l}\text { Qué mano u ojo } \\
\text { inmortal }\end{array}$ \\
\hline $\begin{array}{l}\text { (v4) Could frame thy } \\
\text { fearful symmetry? }\end{array}$ & $\begin{array}{l}\text { ¿Podría enmarcar tu } \\
\text { temible simetría? }\end{array}$ & $\begin{array}{l}\text { ¿Podría enmarcar tu } \\
\text { temible simetría? }\end{array}$ & $\begin{array}{l}\text { ¿Podría enmarcartu } \\
\text { temible simetría? }\end{array}$ \\
\hline
\end{tabular}

In the next table appears the human translation of the poem The Tyger. The translation into Spanish implies the loss of the metric in lyrics number 3 and 4 .

Table 28

\begin{tabular}{|l|l|}
\hline Original text (En) & Human translation (Sp) \\
\hline $\begin{array}{l}\text { (v1) Tyger, tyger, burning bright } \\
\text { (v2) In the forests of the night }\end{array}$ & Tigre, tigre, ardoroso resplandor \\
\hline (v3) What immortal hand or eye & EQ las tinieblas de la selva \\
\hline (v4) Could frame thy fearful symmetry? & pudo enmarcar aquella feroz simetría tan tuya?
\end{tabular}

As we can see in the tables number 25 and $\underline{27}$, the translations from machine translators which use Artificial Intelligence are literal. The problem with literality, especially in poetic texts, is that there is not only a meaning to know but also poetry represents distress, fear, happiness, love, friendship, exile, grief...For this reason, AI 
faces a challenge in order to translate emotions in machine translation. However, in the tables number $\underline{26}$ and $\underline{28}$, translations of both poems are made by humans. The creativity, the capacity of perceiving and transmitting emotions of human beings and the knowledge about the destin language, in this case, Spanish, prevailing at the speed and accuracy of machines.

\section{8.- Conclusions}

The implementation of Artificial Intelligence in translations largely optimizes the productivity and profitability of the task by translating a web page in a few seconds.

This work focuses on the large influence that machine translators have in the process of learning a language. The main problem detected in machine translation is the lack of contextualization. This means that the choice of simplistic words don't help to know the original content of a text to translate, in other words: machines don't know the world, according to Jan-Hendrik Opdenhoff, Vice-Dean of Translation and Interpretation faculty of Granada [47]. Added to the lack of the involvement of informal language and bias gender, we conclude that artificial intelligence in machine translation does not contribute to Spanish language enrichment. For this reason and according to the projects presented in 2021 about how to drive Spanish language in robotics and how to get Artificial Intelligence speaks Spanish [48], we believe that it is needed the regularisation of $\mathrm{AI}$ in machine translation. By this way, we all should contribute to improve and normalise Spanish language and not damage it more.

It would be interesting that regulatories bodies of Spanish linguistic such as the Royal Spanish Academy generates a kind of validator to establish a classificatory list according to machine translators in order to recommend if its usage is plausible or not. It could be a way to improve Spanish practises in the use of machine translators.

\section{9.- Acknowledges}

We thank to organizations and personalities that make possible this project by collaborating on updated information and testimonies which enhance the investigation value.

\section{Footnotes}

1. 2006 se considera la fecha de nacimiento oficial de Google Translate según algunas fuentes: https://www.muycomputer.com/2016/04/29/google-translate-10-

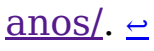




\section{Citations}

1. Wikipedia. (2021). Traductor de Google - Wikipedia, La enciclopedia libre. https://es.wikipedia.org/w/index.php?title=Traductor de Google\&oldid=137788768 2. Yuqo, H. (2019). Nacimiento e historia de la traducción automática. https://www.yuquo.es/nacimiento-e-historia-de-la-traduccion-automatica/ https://www.yugo.es/nacimiento-e-historia-de-la-traduccion-automatica/ $\triangleq$ 3. Gorman, M. (2012). Google gives us some insight on the inner workings of Google Translate. https://www.engadget.com/2012-03-19-google-translate-how-it-works.html? guccounter=1 https://www.engadget.com/2012-03-19-google-translate-how-itworks.html $\triangleq$

4. Wikipedia. (2021). Google. https://es.wikipedia.org/wiki/Google $\underline{-}$ 5. Wikipedia. (2021). Traductor de Google.

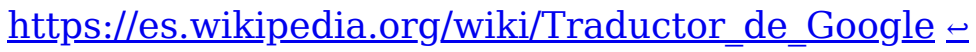
6. Wikipedia. (2021). Microsoft. https://es.wikipedia.org/wiki/Microsoft $\leftrightharpoons$ 7. Wikipedia. (2021). Microsoft Traductor. https://es.wikipedia.org/wiki/Microsoft Translator $\subseteq$ 8. Microsoft. (2021). Traducción Automática. https://www.microsoft.com/eses/translator/business/machine-translation/ $\leftrightharpoons$ 9. Wikipedia. (2020). Linguee. https://es.wikipedia.org/wiki/Traducci\%C3\%B3n_autom\%C3\%A1tica 10. Wikipedia. (2021). DeepL. https://es.wikipedia.org/wiki/DeepL $ヒ$ 11. Wu, Y., Schuster, M., Chen, Z., Le, Q. V., Norouzi, M., Macherey, W., Krikun, M., Cao, Y., Gao, Q., Macherey, K., Klingner, J., Shah, A., Johnson, M., Liu, X., Kaiser, Ł., Gouws, S., Kato, Y., Kudo, T., Kazawa, H., ... Dean, J. (2016). Google’s Neural Machine Translation System: Bridging the Gap between Human and Machine Translation. CoRR, abs/1609.08144. $\subseteq$ 12. Wikipedia. (2021). Neural machine translation. https://en.wikipedia.org/wiki/Neural_machine translation $\triangleq$ 
13. Mohamed I. Khaber 1 , M. S. 1, Abdelouahab Moussaoui 1., \& Frahta2, Nabila. (2021). Deep Neural Transformer Model for Mono and Multi Lingual Machine Translation. $\subseteq$

14. Meza, E. (2020). ¿En qué lenguaje de programación está escrito Google Translate para el procesamiento del lenguaje natural? https://es.quora.com/Enqu \%C3\%A9-lenguaje-de-programaci\%C3\%B3n-est\%C3\%A1-escrito-Google-Translatepara-el-procesamiento-del-lenguaje-natural https://es.quora.com/En-qu\%C3\%A9lenguaje-de-programaci\%C3\%B3n-est\%C3\%A1-escrito-Google-Translate-para-elprocesamiento-del-lenguaje-natural $\subseteq$ 15. Takamori, D. (2019). Apache Joshua Home. https://cwiki.apache.org/confluence/display/JoSHUA/ https://cwiki.apache.org/confluence/display/JOSHUA/ $\triangleq$ 16. Franz Josef Och, H. Ney. (2003). A Systematic Comparison of Various Statistical Alignment Models. Computational Linguistics, volume 29(number 1), 19-51. http://www.fjoch.com/giza-training-of-statistical-translation-models.html $\triangleq$ 17. Moses. (2018). http://www.statmt.org/moses/ $\triangleq$ 18. documentation, G. 3. 0. 0. (n.d.). Googletrans: Free and Unlimited Google translate API for Python \%. https://py_googletrans.readthedocs.io/en/latest/ https://py_ googletrans.readthedocs.io/en/latest/ $\subseteq$

19. Koehn, P. (2020). Statistical Machine Translation. http://www.statmt.org/ http://www.statmt.org $L \uplus$ 20. DeepL. (n.d.). Announcing the Python Client Library for the DeepL API. https://www.deepl.com/es/blog/announcing-python-client-library-for-deepl-api https://www.deepl.com/es/blog/announcing-python-client-library-for-deepl-api 21. Rebollo, M. (2018). ¿Cuáles son los mejores lenguajes de programación para machine learning? https://es.quora.com/Cu\%C3\%A1les-son-los-mejores-lenguajes-deprogramaci\%C3\%B3n-para-machine-learning https://es.quora.com/Cu\%C3\%A1lesson-los-mejores-lenguajes-de-programaci\%C3\%B3n-para-machine-learning $\triangleq$ 22. Vargas, R. (2018). ¿Cuáles son los mejores lenguajes de programación para machine learning? https://es.quora.com/Cu\%C3\%A1les-son-los-mejores-lenguajes-deprogramaci\%C3\%B3n-para-machine-learning https://es.quora.com/Cu\%C3\%A1les-

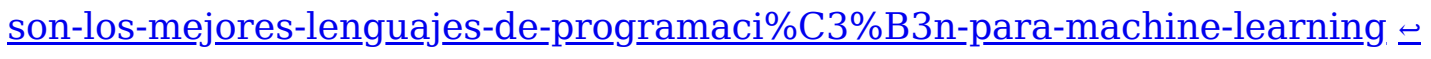


23. ALPAÑÉS, E. (2021). Google Translate: fortalezas y límites de la amenaza que los traductores convirtieron en herramienta. https://elpais.com/tecnologia/2021-0225/google-translate-fortalezas-y-limites-de-la-amenaza-que-los-traductoresconvirtieron-en-herramienta.html https://elpais.com/tecnologia/2021-02-25/googletranslate-fortalezas-y-limites-de-la-amenaza-que-los-traductores-convirtieron-enherramienta.html $\triangleq$

24. Wikipedia. (2021). BERT (modelo de lenguaje).

https://es.wikipedia.org/wiki/BERT_(modelo de lenguaje $)$. https://es.wikipedia.org/wiki/BERT_(modelo de lenguaje $).$ 25. Peltarion. (2021). Webinar: How NLP and BERT will change the language game. https://peltarion.com/webinars/nlp-and-bert https://peltarion.com/webinars/nlp-and$\underline{\text { bert }} \leftrightarrows$

26. blog, M. T. (2017). Microsoft Translator acelera el uso de redes neuronales a través de sus ofertas. https://www.microsoft.com/eses/translator/blog/2017/11/15/microsoft-translator-accelerates-use-of-neuralnetworks-across-its-offerings/ https://www.microsoft.com/eses/translator/blog/2017/11/15/microsoft-translator-accelerates-use-of-neuralnetworks-across-its-offerings/

27. Wiggers, K. (2021). Microsoft taps AI techniques to bring Translator to 100 languages. https://venturebeat.com/2021/10/11/microsoft-taps-ai-techniques-to-bring= translator-to-100-languages/ https://venturebeat.com/2021/10/11/microsoft-taps-aitechniques-to-bring-translator-to-100-languages/ $\doteq$ 28. Beatrice Savoldi, M. N. et M. T., Marco Gaido1,2, Luisa Bentivogli. (2021). Gender Bias in Machine Translation. Fondazione Bruno Kessler et University of Trento. $ヒ$

29. Stella, R. (2021). A Dataset for Studying Gender Bias in Translation. https://ai.googleblog.com/2021/06/a-dataset-for-studying-gender-bias-in.html https://ai.googleblog.com/2021/06/a-dataset-for-studying-gender-bias-in.html 30. Argentina Anna Rescigno, A. W., Eva Vanmassenhove, Johanna Monti. (2020). A Case Study of Natural Gender Phenomena in Translation A Comparison of Google Translate, Bing Microsoft Translator and DeepL for English to Italian, French and Spanish. CEUR-WS, 1. http://ceur-ws.org/Vol-2769/paper_26.pdf $\triangleq$ 
31. Romero, M. S. (2021). El sesgo de género del Traductor de Google persiste: Ella cose, él conduce. https://computerhoy.com/noticias/tecnologia/sesgo-generotraductor-google-persiste-ella-cose-conduce-834637 https://computerhoy.com/noticias/tecnologia/sesgo-genero-traductor-google-persisteella-cose-conduce-834637 $\leftrightarrows$ 32. ALPAÑÉS, E. (2021). Google Translate: fortalezas y límites de la amenaza que los traductores convirtieron en herramienta. https://elpais.com/tecnologia/2021-0225/google-translate-fortalezas-y-limites-de-la-amenaza-que-los-traductoresconvirtieron-en-herramienta.html @ONLINE \{enriquealpañés2021, author = "ENRIQUE ALPAÑÉS", title = "Google Translate: fortalezas y límites de la amenaza que los traductores convirtieron en herramienta", month = "feb", year = "2021", url = "https://elpais.com/tecnologia/2021-02-25/google-translate-fortalezas-y-limites-de-laamenaza-que-los-traductores-convirtieron-en-herramienta.html "\} 33. Alonso, C. H. (1991). El lenguaje coloquial juvenil. $\subseteq$ 34. de Chile, E. (2021). Spoiler. http://etimologias.dechile.net/?spoiler http://etimologias.dechile.net/?spoiler $\triangleq$ 35. RAE. (2021). Diccionario de la Real Academia Española. https://www.rae.es/ https://www.rae.es/ 36. de Chile, E. (2021). Etimología Hashtag. http://etimologias.dechile.net/?hashtag http://etimologias.dechile.net/?hashtag $\leftrightarrows$ 37. Languages, O. (2021). Origin of smartphone. https://languages.oup.com/google$\underline{\text { dictionary-es/ }} \triangleq$

38. Prieto, P. D. (2012). Luces y sombras en los 75 años de traducción automática. $ヒ$ 39. de la Lengua Española, R. A. (2021). Definición de ambiguo.

https://dle.rae.es/ambiguo?m=form https://dle.rae.es/ambiguo?m=form 40. Pericliev, V. (1984). Handling syntactical ambiguity in machine translation. Proceedings of the 22nd Annual Meeting on Association for Computational Linguistics -. the 22nd annual meeting. https://doi.org/10.3115/980491.980602 41. Wikilengua. (n.d.). Ambigüedad. https://www.wikilengua.org/index.php/Ambig\%C3\%BCedad $\triangleq$ 
42. wikipedia. (2021). Ambigüedad.

https://es.wikipedia.org/wiki/Ambig\%C3\%BCedad $\triangleq$

43. Bitbrain. (2018). Neurotecnología - Investigación.

https://www.bitbrain.com/es/blog/inteligencia-artificial-emociones

44. BARBIERI, A. (2019). Traductores e intérpretes, ¿las próximas víctimas de la inteligencia artificial?

https://www.lavanguardia.com/tecnologia/20190601/462559134761/traductoresinterpretes-victimas-inteligencia-artificial-google-translate.html https://www.lavanguardia.com/tecnologia/20190601/462559134761/traductoresinterpretes-victimas-inteligencia-artificial-google-translate.html $\leftrightharpoons$

45. Wikipedia. (2021). Robert Frost. https://es.wikipedia.org/wiki/Robert Frost 46. Wikipedia. (2021). William Blake. https://es.wikipedia.org/wiki/William Blake $\leftrightharpoons$ 47. IDEAL. (2018). El gran problema de los traductores automáticos. https://www.ideal.es/sociedad/malas-interpretaciones-20180129003459-ntvo.html?

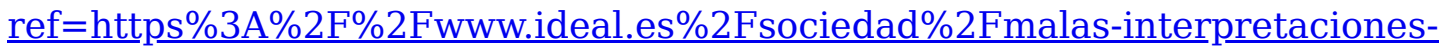
20180129003459-ntvo.html https://www.ideal.es/sociedad/malas-interpretaciones20180129003459-ntvo.html? ref=https $\% 3 \mathrm{~A} \% 2 \mathrm{~F} \% 2 \mathrm{Fwww} . \mathrm{ideal} . \mathrm{es} \% 2 \mathrm{Fsociedad} \% 2 \mathrm{Fmalas}-\mathrm{interpretaciones-}$ 20180129003459-ntvo.html $\leftrightharpoons$

48. Español, E. (2021). Cuanto más apoyo al español, mejor. https://www.elespanol.com/opinion/editoriales/20211002/apoyo-espanolmejor/616328363 14.html https://www.elespanol.com/opinion/editoriales/20211002/apoyo-espanolmejor/616328363_14.html $\leftrightharpoons$ 